\title{
Profiling Smallholder Farmers Goals and Aspirations for Enhanced Agricultural Development: a Case
} of Smallholder Maize Farmers

\author{
Fakunle Olufemi Oyedokun*, Zhou Leocadia \\ Risks and Vulnerability Assessment Center, University of Fort Hare, Alice, South Africa \\ ofakunle@ufh.ac.za*, LZhou@ufh.ac.za
}

\begin{abstract}
The intervention of government in the development of smallholder agriculture is still grappling and has not yielded the desired results, despite the huge investment from government. This has been a source of concern to government and policy makers. This paper sought to analyze the socio-demographic features of the smallholder maize farmers; profile the goals and aspirations of these farmers; and lastly, to analyze the technical efficiency of maize farmers. Qamata and Tyefu in the Transkei and Ciskei homelands, respectively were purposively chosen for the study. Descriptive statistics; Principal component analysis (PCA) and stochastic frontier analysis (SFA) were used in the analysis. The result shows, that majority (66\%) of the farmers were males with an average range of 61 years old. On the other hand, the PCA indicated that there is a variation between predicted goals and aspiration among maize farmers. The SFA result showed that farmers were efficient. The mean technical efficiency estimates up to $100 \%$, an indication that farmers are more efficient in the usage of factors of production at their disposal in the study area. This implies that smallholder maize farming is lucrative due to its profit-making potentials. Moreover, this is a clear indication that more income and wealth is generated thereby implying that it is strategic and pivotal in improving farmers' livelihoods
\end{abstract}

Keywords: Aspirations, goals, smallholder, socio-demographic, technical efficiency

\section{Introduction}

Some of the notable theorists that have taken up the Adler's notion of goal and given it more concreteness include McClelland and Atkinson. Some of the most important contributions of these theorists that are relevant to the discussion of farm problems and economic participation deal with the motivational process. To these theorists, goal attainment is a central element of human behavior. How the human being goes about trying to attain the goals constitutes the motivational process and helps to clarify how goals influence the choices that individuals make. This insight has been provided by the theory put forward by McClelland (1987) in which they illustrated the sequence of activities associated with goal attainment. The main element of the process is that the individual responds to impulses both within himself or herself and defined by the unique personality and a set of environmental influences that come from experience of either a transient or permanent nature (Diecidue and De Ven, 2008). The first thing a successful person needs to have in life is a goal. Goals have been defined in various ways. Commonly, goals and objectives are considered to be an individual wishes to achieve or a state in which an individual wishes to be in (Locke, 2010). On the other hand, (Harper, 2010) explains that goals are ends of objectives or a state at a farmer wishes to achieve or gaining a more desired need. Thus, an aspiration is a goal or objective that a human being strongly desires to achieve. Goals sustain, empower, and give purpose to human's directions in life towards ultimate fulfillment and happiness. The assessment of farmers goals serve as a number of useful purposes. Firstly, understanding farmers' goals can be useful in forecasting his economic behavior, secondly; multiple goals of farmers can be integrated into farm simulation models to assist producers in decision-making and finally, knowledge of farmers' goals is desirable for the formulation of agricultural policy and extension programs. These are necessary steps towards devising alternative ways of goals. Therefore, it is important smallholder farmers are able to identify their goals. Kodua-Agyekum (2009) further concede that the outcomes of previous research indicate that the management behavior style of every farmer is rooted in their goals, values and attitudes

However, attempts to equate the relationship between attitude and behavior show that it is not the same as specified, (Beedell and Rehman, 2000). This complexity is reflected in the farmers' behavior which is rarely a result of a single category of influences. Schoon and Grotenhuis (2000) explain some of these complexities are more or less generally established values that influence farmers in a more or less direct way. There is a complex relationship when working on objectives and behaviors because they are subject to controlled from resource constraints (Errington and Gasson, 1994). Previous researches support the idea that landholder 
values lead to landholder behavior (Maybery, Crase and Gullifer, 2005). In line with the roles that values play in shaping the farm managers' goals, sometimes farm manager needs to act more in a complex situation, so that no behavior is judged as being necessarily right or wrong. In other words, their behavior is appraised by whether it is in agreement with the managers' values (Maybery, Crase, and Gullifer 2005). Although a set of values can change goals and objectives, as well as the real expression of these values can equally change, this can be in response to changes in the external environment or to the farmers' changing their internal environment (Errington and Gasson, 1994). However, research indicates that the goals and aspirations of smallholder farmers in South Africa continues to be hampered and efforts are being made towards addressing those structural constraints that inhibit the growth of a vibrant commercial smallholder sector. Such problems include lack of market, poor storage and poor packaging of the produce and product for market sales, and could lead to high economic losses which could invariably affect the profitability, as well as the livelihood status of the farmers. In this paper, we first of all tried to analyze the socio-economic features of the smallholder maize farmers; and secondly analyzed the technical efficiency of smallholder maize enterprise in line with their factor inputs and outputs implication, as well as comparing them in line with their smallholder irrigators and homestead maize gardeners in Eastern Cape Province of South Africa.

\section{Methodology}

The study was conducted in Eastern Cape Province (ECP) of South Africa. The province is one of the nine provinces of South Africa, sharing borders with the provinces of the Western Cape, the Free State, KwaZuluNatal and Lesotho in the north (Eastern Cape Provincial Legislature, 2003). Thirty nine (39) municipalities are in the area of which thirty seven (37) and two (2) are categorized as local and metropolitan municipalities, respectively. The province is also known as the traditional home of the Xhosa tribal group of South Africa. The vast interior of the ECP ranges from the dry Karoo in the west to the rolling hills and cascading rivers of the Transkei in the East. It is made up of two regions: the Western and the Eastern regions. The area lies within latitudes and longitudes 32000 /S and 26000/E (Map of the World, 2014). The province has a land area covering approximately $169,580 \mathrm{sq} . \mathrm{km}$, which is about $13.9 \%$ of the South African total area (Eastern Cape Department of Rural Development and Agrarian Reform (ECDRAR), 2011). Out of the 51, 770, 560 persons which make up South Africa's total population, the area is estimated to have 6,562,053 persons (Statistics South Africa, 2012). In order words, the population of people living in the rural area accounted for $60 \%$ of the total population.

The demographic features of ECP is characterized by high level of illiteracy, high level of poverty, high unemployment rate, poor infrastructural facilities and lack of other basic amenities. According to ECDRAR (2011) and ECSECC (2011), the contribution of agriculture to the GDP of the area has been on the decline. Purposive and random sampling techniques were used in the study. Through stakeholder meetings with the officials of the Department of Rural Development and Agrarian Reform (DRDAR), and officials at the Municipal offices, as well as the community members Information regarding the operational status of the irrigation schemes in the province was adequately accessed. The outcome of the meeting lead to the identification of the two smallholder irrigation schemes in the surrounding communities. Out of the thirty seven (37) municipalities that make up the ECP of South Africa, two (2) municipalities namely: Qamata and Tyefu irrigation schemes were purposively chosen because they are considered the largest small-scale irrigation schemes in the Transkei and Ciskei homelands, respectively. A research team was involved in data collection and sought support from extension officers and community authorities. In selecting seventy (70) smallholder maize farmers in Qamata area, and thirty nine (39) smallholder maize farmers in Tyefu area, a random selection technique was adopted. A total of 70 farmers' were interviewed in Qamata and 39 farmers in Tyefu, respectively. In all, 109 smallholder maize farmers was interviewed in the study areas

Descriptive statistics: Descriptive statistics, frequency tables and percentages were adopted in describing the socio-economic features of the smallholder maize farmers in the study area.

Principal component analysis: The principal component (PC) of a given dataset of $\mathrm{P}$ numeric variables can be presented mathematically as:

$$
P C_{n}=f\left(a_{n i} X_{i}, \ldots \cdots \cdots \cdots \cdots \cdots \cdots \cdots \cdots a_{1 j} X_{j}\right)
$$


Where $P C$ is the principal component, $\mathrm{n}$ represents a number greater than one. The $P C$ can take different forms of measurement and these include continuous variables, quantity of related products of values that make up a component, and weighted values or generated values from the component loading. $a_{1 j}$ is the regression coefficient for the $j^{\text {th }}$ variable and it is known as the eigenvector of the covariance matrix between variables. $X_{j}$ is the value of the $j^{\text {th }}$ variable. Explicitly the equation can be written as:

$$
P C_{1}=a_{11} X_{1}+a_{12} X_{2}+\ldots \ldots \ldots \ldots . a_{i j} X_{j}
$$

Where $P C_{1}=$ first principal component.

The first and second independent variables of $P C_{1}$, are $\mathrm{X}_{1}$ and $\mathrm{X}_{2}$ in the linear additive model needed to derive the principal component, and the $a_{11}$ and $a_{12}$ are coefficient (component loadings) associated with the $X_{1}$ and $X_{2}$ variables.

Stochastic frontier analysis: The Stochastic Frontier Analysis was engaged to calculate approximately the technical Efficiency of smallholder farmers. The outcomes of this analysis were used to establish resource use efficiency of farmers. This will be used to advice the farmers and suggest the best enterprises to invest for a more efficient, profitable and sustainable farming business among the small holder irrigation schemes in the Eastern Cape Province. According to Battese and Coelli (1992) Technical efficiency of a given enterprise was estimated using a stochastic Production Frontier, which can be specified as

$$
\ell=V-U
$$

Technical efficiency levels are estimated from the stochastic frontier analysis. Following 0jo (2003), this research determined the stochastic frontier production function using the flexible log linear Cobb- Douglas production function.

$$
Y=f\left(X_{i} ; \beta\right)+\ell
$$

\section{Results and Discussion}

Socio-Economic Features of Smallholder Maize Farmers: Gender, age, marital status, household size, occupation and number of years spent in smallholder maize enterprise were some of the demographic characteristics of the respondents that were studied.

Gender Distribution of the Household Head: Gender is said to determine to a great extent farmers' involvement in farming practices which they engage in. This is because such agribusiness practices are gender specific. This is the reason why data was collected on gender of the units interviewed and presented in Table 1.

Table 1: Distribution of the sample according to the Gender of the Household Head

\begin{tabular}{lcl}
\hline Sex & Frequency & Percentage \\
\hline Male & 72 & 66.1 \\
Female & 37 & 33.9 \\
Total & 109 & 100.0 \\
\hline
\end{tabular}

Source: Field Survey Data, 2014.

Table 1 shows the relationships between both genders. From the table, it could be deduced that there are more males as compared to females with the $72 \%$ out of the totality of the sample being men, and $37 \%$ representing the total number of females who were interviewed. This agrees with a study by KoduaAgyekum (2009) that more dry agricultural lands were allocated to males as a result of their bias of their African rules and norms.

Age Distribution of the Household Heads: Age is an important factor in diverse agricultural enterprises, and most socio-economic studies have shown that age is inversely related to performance (Agbugba, Nweze, Achike and Obi, 2013). In due course, data was collected on the age distribution of the farmers interviewed. The results were presented in Table 2 . 
Table 2: Distribution of the Household heads according to their Ages

\begin{tabular}{lll}
\hline Age & Frequency & Percentage \\
\hline $35-40$ & 18 & 16.51 \\
$41-45$ & 9 & 8.26 \\
$46-50$ & 14 & 12.85 \\
$51-55$ & 22 & 20.18 \\
$56-60$ & 9 & 8.26 \\
$61-65$ & 35 & 32.11 \\
$66-70$ & 2 & 1.83 \\
Total & 109 & 100.0 \\
\hline
\end{tabular}

Source: Field Survey Data, 2014

Results from Table 2.0 shows that the average age of the household head among smallholder farmer is about 61 years; this implies that both the Qamata and Tyefu might be operating under less productive status due to their age which is considered to be weak compared to youthful age which seems to be more productive (Ogundele and Okoruwa, 2006). Most of the youth in the area may not be interested in farming work thus, left the area in search of more paying employment (Obi and Pote, 2012) and for a white collared job, thereby creating a gap in age distribution.

Marital Status Distribution of the Household Heads: Marital status is also a crucial factor in the farming profession. A high proportion of married respondents suggest an additional supply of labor from the family (Ezihe, Agbugba and Iornum, 2014). In view of this study, data was collected on the marital status of smallholder maize farmers, and Table 3 presented the results.

Table 3: Distribution of the Household heads according to their Marital Status

\begin{tabular}{lll}
\hline Marital Status & Frequency & Percent \\
\hline Married & 75 & 68.81 \\
Single & 5 & 4.58 \\
Divorced & 14 & 6.42 \\
Widow & 19 & 17.44 \\
Widower & 3 & 2.75 \\
Total & 109 & 100.0 \\
\hline
\end{tabular}

Source: Field Survey Data, 2014

From Table 3, the marital status of farmers is an important element in farming enterprise. Therefore, its importance is prominent as farming households use it as an advantage in providing family labor. The results indicated that majority (69\%) of the respondents are married, $6 \%$ divorced, $5 \%$ are single while the rest $(20 \%)$ of the respondents are widowed.

Household Size Distribution of the Farmers: Household size has a very important bearing with business and income (Enete and Agbugba, 2008). This was the reason why data was collected on household size. The results of the distribution of the farmers according to their household sizes are presented in Table 4.

Table 4: Distribution of the Farmers according to their Household size

\begin{tabular}{lll}
\hline Household Size & Frequency & Percentage \\
\hline $1-4$ & 60 & 55.05 \\
$5-6$ & 36 & 33.03 \\
$7-9$ & 11 & 10.09 \\
$10-$ Above & 2 & 1.83 \\
Total & 109 & 100 \\
\hline
\end{tabular}

Source: Field Survey Data, 2014

Similarly, Table 4 indicated that the household sizes of the respondents engaged family members in farming. However, in this case, a family with 4 members has the highest frequency distribution (55\%). Households with $5-6$ persons have $33 \%$ of the total respondents, while $2 \%$ of the population has a family size greater than 
10 persons. In essence, the use of family labor helped reduce the cost that would have been spent on hired labor. The implication of this is that more cost will be incurred due to more hired labor employed to supplement the family labor (Ezihe et al., 2014).

Table 5: Distribution of the household heads according to the number of years spent in Maize farming

\begin{tabular}{llc}
\hline Number of years & Frequency & Percentage \\
\hline $1-2$ & 17 & 18.5 \\
$3-5$ & 11 & 13.5 \\
$6-8$ & 19 & 21 \\
$9-11$ & 46 & 33 \\
$11-$ Above & 16 & 14.0 \\
Total & 109 & 100 \\
\hline
\end{tabular}

Source: Field Survey Data, 2014

Table 5 indicated that the number of years spent in maize farming is an important factor as it relates to the farmers' experience, and will in turn reflect the effectiveness of an agro- enterprise in order to yield a reasonable output. The results further revealed that, a majority (33\%) of maize farmers spent between 9 and 11 years in the farming, thereby implying that most of the maize farmers are homestead food gardeners and smallholders.

Distribution of Household heads based on their Primary Occupation: Primary occupation is the occupation in which households spends $75 \%$ and above of their time, and from which they earn a greater proportion of their income (Echebiri, 2001). This was the reason why data were collected on the primary occupation of maize farmers and the results of the distribution is presented in Table 6.

Table 6: Distribution of household heads according to their primary occupation

\begin{tabular}{lll}
\hline Occupation & Frequency & \multicolumn{1}{c}{ Percent } \\
\hline Farming & 97 & 89.00 \\
Trading & 1 & 0.92 \\
Casual Worker & 5 & 4.58 \\
Civil Servant & 4 & 3.67 \\
Student & 2 & 1.83 \\
Total & 109 & 100.0 \\
\hline
\end{tabular}

Source: Field Survey Data, 2014

Table 6 shows that about $89 \%$ of smallholder farmers considered maize farming as their primary occupation in Qamata and Tyefu, respectively. This gave a negative signal as it indicated a high level of unemployment in the area. In estimating farmers' goals and attitudes as presented in Table 7, principal component analysis was used.

This method was used because of its ability to condense the twenty one (21) goal and attitudinal related statements into fewer ones. In the course of the analysis, some statements were dropped to achieve fair results that correspond with the minimum Kaiser-Meyer-Olkin Measure (KMO) of Sampling Adequacy value of 0.60 and to get the Bartlett's Test of Sphericity. It was observed that the KMO value for this particular analysis was 0.64 and passed the Bartlett's Test of Sphere and there is no autocorrelation among variables. The Eigen value proportions of the variance for the selecting optimal number of principal components were above the suggested value of 1 . The two mandatory tests were passed by eleven out of twenty one goal and attitudinal related statements and were further subjected into factor loading statistical measurement stage. Four principal components were yielded from these eleven goal and attitudinal statements that explained $68.52 \%$ of the variation in the explanatory variables. Farm status/expressive (PC1), business (PC2), social (PC3), and independence oriented goals (PC4) are the four principal components that were yielded. Farm status was the first principal component displayed with a variation of about $25.16 \%$ in the famers' rankings of their goals. These components are best described as a farm status, expressive or self-esteem oriented goals. Goal related statements by farmers that have estimated coefficients above 0.30 and defined this principal component were six in number. Most of these farmers had an interest of being attached to the successes on 
their farms. All the four expressive or self-esteem related goals are part of the farmers' goals that explain the first principal component. In this case, the self-esteem or confidence may be of great importance to farmers for better performance as they strive to achieve these goals. Although the principal component was mainly described by the farm status/self-esteem goals, it has some elements of business oriented goals such as, an increase in maximum incomes and building up wealth in greater dimension.

Table 7: Profiling smallholder farmers goals and aspiration

\begin{tabular}{|c|c|c|c|c|}
\hline & Farm Status & $\begin{array}{l}\text { Business } \\
\text { Oriented }\end{array}$ & $\begin{array}{l}\text { Social } \\
\text { oriented }\end{array}$ & Independence \\
\hline Proportion of Variation (\%) & 25.16 & 19.70 & 14.07 & 9.60 \\
\hline \multirow{2}{*}{ Eigen Value } & 2.767 & 2.167 & 1.548 & 1.056 \\
\hline & \multicolumn{4}{|c|}{ Factor Loadings } \\
\hline Farmers' Goal and aspiration & PC1 & PC2 & PC3 & PC4 \\
\hline Self-employed and independent & -0.036 & 0.516 & 0.135 & 0.478 \\
\hline Have more leisure time & -0.070 & -0.143 & $\underline{0.552}$ & 0.697 \\
\hline Be recognized as top producer & $\underline{0.768}$ & $\underline{-0.352}$ & 0.208 & 0.044 \\
\hline $\begin{array}{l}\text { Be recognized as a leader in the technology } \\
\text { adoption }\end{array}$ & $\overline{0.754}$ & $\overline{-0.428}$ & -0.083 & 0.085 \\
\hline $\begin{array}{l}\text { Be recognized as a specialist in growing these } \\
\text { crop }\end{array}$ & $\underline{0.853}$ & -0.136 & 0.008 & 0.053 \\
\hline Be recognized as owner of the land & $\underline{0.405}$ & $\underline{-0.323}$ & $\underline{-0.546}$ & 0.185 \\
\hline $\begin{array}{l}\text { Contacts with people, and transfers of } \\
\text { information }\end{array}$ & $\overline{0.077}$ & $\overline{0.015}$ & $\underline{\underline{0.792}}$ & -0.278 \\
\hline Social participation: meetings and rituals & 0.257 & $\underline{0.589}$ & -0.284 & $\underline{0.345}$ \\
\hline Increase standards of living & 0.193 & 0.776 & -0.191 & -0.030 \\
\hline Increase maximum farm income & 0.555 & 0.546 & 0.024 & $\underline{-0.300}$ \\
\hline Accumulate wealth & $\underline{0.541}$ & $\underline{0.450}$ & 0.362 & -0.089 \\
\hline \multicolumn{5}{|c|}{ Kaiser-Meyer-Olkin Measure (KMO) of Sampling Adequacy $=0.643$} \\
\hline \multirow{2}{*}{\multicolumn{5}{|c|}{$\begin{array}{l}\text { Bartlett's Test of Sphericity Approx. Chi-Square = } 342.739 \\
\mathrm{df}=55\end{array}$}} \\
\hline & & & & \\
\hline Model significance level = $1 \%$ & & & & \\
\hline
\end{tabular}

Source: Result from SPSS (version 11) generated from field survey, 2014. Where ${ }^{* * *}{ }^{* *}$ and* are significant levels at $1 \%, 5 \%, 10 \%$ respectively.

The second principal component which primarily consists of business and developmental farmer's related goals accounted for $19.70 \%$ of variation in the variables. The goals are improved standards of living, maximization of farm incomes and increase in wealth buildup. With the low output and less marketable surplus produced by these smallholder farmers, they still view farming as one of the major sources of livelihood. Vegetables and maize are the major plants grown by the smallholder farmers in Qamata and Tyefu irrigation scheme area and they are being sold within local markets around them to earn a living. Other important vegetables grown for sale included potatoes, cabbages, carrot and spinach, among others. Farmers' business oriented goals can be of great importance in increasing production and resulting in marketable surplus. Business goals of these smallholder farmers can therefore, be incorporated in rural development programs for improved smallholder incomes and general livelihood of the rural poor farmers.

Determination of Technical Efficiency of Smallholder Maize Farmers: The parameters and related statistical results obtained from the stochastic production function are presented in Table 8. The coefficient $(\beta$ 's) presented in this table represent the elasticities of the various inputs used in maize production due to the assumption of half-normal distribution of the data use in the model (Greene, 2002). In Table 10, seed, fertilizer, herbicides and HCI were positive and significant factors which indicate that the use of these factors was profitable and as such that a unit increase in these inputs will eventually result in an increase in maize output of the farmers. This result conform to the findings of Essilfie, Asiamah and Nimoh (2011) that seed is positive and significant factors and as such, a unit increase in this input will eventually result in an increase in maize output of the farmers. Furthermore, the result also agrees with the findings of Geta, Bogale, Kassa and Elias (2013) where they established a positive and significant relationship that farmers who apply higher 
fertilizer rates receive higher rates of yield. Therefore, this implies that increasing the rate of seed, fertilizer and herbicide usage would significantly increase maize productivity. Pesticide showed a positive relationship, but insignificant with respect to yield. This could imply that farmers are under-utilizing this variable, and therefore, there is need to increase its usage as it responds more to output. However, the emerging results disagrees with the findings of Lamini, Masuku and Rugambisa (2012) that indicated a positive and significant effect of pesticide usage on maize production. In the study area, the predicted technical efficiencies varied substantially among the maize farmers in the area with mean technical efficiency estimate to be $100 \%$. This is an indication that farmers in this area are more efficient in the usage of factors of production at their disposal. On the other hand, in addition to the goals and aspiration, socio-demographic factors of Sex, Marital status, Age and Goals which belonged to the inefficiency model were all positive factors but insignificant to the yield of maize.

Table 8: Technical Efficiency Results of Half-Normal Distributions (with Goal)

\begin{tabular}{|c|c|c|c|c|c|}
\hline Variable & Parameters & Coefficient & Std. Error & $\mathbf{Z}$ & P-Value \\
\hline \multicolumn{6}{|c|}{ Stochastic Frontier } \\
\hline Intercept_ & $\mathrm{B}_{0}$ & 127.55 & 4362.11 & 0.03 & 0.98 \\
\hline Seeds & $\mathrm{B}_{1}$ & 29.89 & 3.96 & 7.55 & $0.00^{* *}$ \\
\hline Fertilizer & $\mathrm{B}_{2}$ & 5.73 & 1.31 & 4.37 & $0.00^{* *}$ \\
\hline Pesticides & $\mathrm{B}_{3}$ & -34.10 & 80.19 & -0.43 & 0.67 \\
\hline Herbicides & $\mathrm{B}_{4}$ & 81.77 & 37.15 & 2.20 & $0.03^{* *}$ \\
\hline HCI & $\mathrm{B}_{5}$ & 1106.06 & 200.83 & 5.51 & $0.00^{* *}$ \\
\hline \multicolumn{6}{|c|}{ Inefficiency Model } \\
\hline Sex_hhh & & 175.09 & 163.03 & 1.07 & 0.28 \\
\hline Marital Stat & & 51.62 & 161.60 & 0.32 & 0.75 \\
\hline Age & & -10.93 & 6.71 & -1.63 & 0.10 \\
\hline Year_School & & 23.42 & 19.43 & 1.21 & 0.23 \\
\hline Goalorient & & -1.86 & 3.79 & -0.49 & 0.62 \\
\hline \multicolumn{6}{|c|}{ Variance Parameter } \\
\hline Sigma_v & & 637.0 .1 & 43.34 & & \\
\hline Sigma_u & & 0.08 & 5410.25 & & \\
\hline Sigma2 & & 405784.9 & 55222.77 & & \\
\hline Lambda & & 0.00 & 5410.66 & & \\
\hline Log likeliho & & & -850.58 & & \\
\hline Wald chi2 & & & 532.46 & & \\
\hline Mean techn & ficiency & & $100.00 \%$ & & \\
\hline
\end{tabular}

Source: Model results (2015) ( ${ }^{* *}$ is $1 \%$ or $5 \%$ levels of significance)

From the results in Table 8, goals and aspirations is a positive relationship, but insignificant to the yield of maize. Therefore, we can state that goals and aspirations are not significant to technical efficiency. This may imply that the goals and aspirations of maize farmers are in line with the productive factors.

\section{Conclusion}

Goals and aspirations were found to have a significant impact on farming among smallholder maize farmers living in Qamata and Tyefu. It is imperative for the government and other stake holders to start on providing appropriate policy statements that will enhance the goals and aspirations of smallholder farmers through intervention programs given by the government. When government intervention is in agreement with the goals and aspirations of farmers then, the results will be worth the investment and the outcome will be of value to the communities. In addition, adoption of technologies which have a low cost of production, time and labor effective strategies should be designed; this will have social and psychological benefits to all the smallholder farmers and the communities at large. Furthermore, with the provision of more suitable technologies, the government and other development partners should set up an enabling environment to develop farmers' business growth. These may include creating a standard market access, organization of agro-based small scale industries that are fed with primary agricultural outputs for value addition. In 
addition, business management trainings for improved technical efficiency should be included in the curriculum of these farmers during various training programs. An enabling environment also is essential for improved positive goals and aspirations since it instills hope and confidence among smallholder farmers. In all, an efficient farmer will tend to value independence goal in maize production and success of the farm (selfesteem) goals to positively and significantly influence maize technical efficiency. In view of this, a grounded policies that will enhance and promote farming as self-employment opportunity with less direct intervention of the external agencies should be formulated, for increased job creation and improved rural livelihood which is one of the goals and aspirations of the farmers identified in this study.

Acknowledgement: The authors wish to express appreciation to Govan Mbeki Research Development Centre (GMRDC).

\section{References}

Agbugba, I. K., Nweze, N. J., Achike, A. I. \& Ajuruchukwu, O. (2013). Market Structure, Conduct, Channel and Margin of Dry Season Okra Vegetable in South-Eastern Nigeria. From: http://www.ipcbee.com/vol55/014-ICFAS2013-G2023.pdf). (Retrieved on 20 February, 2015).

Battese, G. E. \& Coelli, T. J. (1992). Frontier production function, technical efficiency and panel data: with application to paddy farmers in India. Kluwer academic publisher.

Beedell, J. \& Rehman, Y. (2000). Using social-psychology models to understand farmer's conservation behaviors. Journal of Rural Studies, 16(1) 117-127.

Diecidue, L. \& Van De Ven, J. (2008). Aspiration level, probability of success and failure and expected utility. International Economic Review, 49(2) 685-700.

Eastern Cape Department of Rural Development and Agrarian Reform (ECDRAR). (2011). Strategic Plan 2010/11-2014/15 (updated 2011/12); Towards Vibrant, Equitable \& Sustainable Rural Communities \& Food Security.

Eastern Cape Provincial Legislature. (2003). Strategic Plan 2003-2006. From: http://www.treasury.gov.za/documents/provincial\%20budget/2003/Strategic\%20Plans/Eastern\% 20Cape/EC\%20-\%20Vote\%2002\%20-\%20Legislature.pdf (Retrieved on 20 February, 2015).

Eastern Cape Socio-Economic Consultative Council (ECSECC). (2011). Quarterly Economic Update, Fourth Quarter, ECSECC, March 2011.

Echebiri, R. N. (2001). An Analysis of the Influence of Socio-Economic Variables on Household Income, Consumption Expenditure and Savings in Rural Southeastern Nigeria. PhD. Thesis, Unpublished. Nsukka: University of Nigeria Nsukka.

Enete, A. A. \& Agbugba, I. K. (2008). Charcoal Marketing in Abia State of Nigeria. Proceedings of the 22nd Annual National Conference of the Farm Management Association of Nigeria, Abia State: Nigeria pp 338-346.

Errington, A. \& Gasson, R. (1994). Labor use in the farm family business. Sociologia ruralis, 34(4), 293-307.

Essilfie, F. L., Asiamah, M. T. \& Nimo, H. (2011). Estimation of farm level technical efficiency in small scale maize production in the Mfantseman municipality in the central region of Ghana. Accademicjournal.org

Ezihe, J. A. C., Agbugba, I. K. \& Iornum, W. (2014). Economic Assessment of Rural Women Participation in Processing and Marketing of Soybean in Tarka LGA of Benue State Nigeria. African Journal of Agriculture Research, 2(1), 99-107.

Fan, S. (2009). Setting Priorities for Public Spending for Agricultural and Rural Development in Africa Policy Brief 12, IFPRI.

Fakunle, O. O. (2015). Motivational characteristics and trends in commercialization of smallholder farming in Eastern Cape Province of South Africa. PhD. Thesis, Unpublished. Alice: University of Fort Hare.

Greenberg, S. (2013). Smallholders and agro-food value chains in South Africa. Emerging practices and emerging challenges, Institute for Poverty Lands and Agrarian Studies, School of Government, FEEMS, UWC. $\quad$ From: http://www.plaas.org.za/1A22E026-0703-4760-9A66A5EE60570290/FinalDownload/DownloadId9775CF1A8E71E6AC3A1256EEBDFEF509/1A22E0260703-4760-9A66-A5EE60570290/sites/default/files/publications pdf/value\%20chains\%

20web.pdf (Retrieved on 20 February 2015).

Greene, W. H. (2002). Econometric Analysis. New Jersey: Prentice Hall 
Geta, E., Bogale, A., Kassa, B. \& Elias, E. (2013). Productivity and efficiency analysis of smallholder maize producers in Southern Ethiopia. Journal of Human Ecology, 41(1) 67-75

Harper, S. (2010). Implicit value judgments in the measurement of health inequalities. Online library.willey.com

Kodua-Agyekum, C. (2009). The transfer of technology to the rural poor: The case of Qamata Irrigation Scheme in the Eastern Cape Province of South Africa, PhD Thesis, Unpublished. Kwazulu-Natal: University of Kwazulu-Natal, South Africa.

Lamini, D., Masuka, M. B. \& Rugambusa, K. (2012). Technical efficiency of maize production in Swaziland. A stochastic frontier approach. Africa Journal of academic. Org

Locke, J. (2010). Loneliness, friendship quality and the social networks of adolescents. Onlinelibrary.willey.com

Maybery, D., Lin, C. \& Gullifer, C. (2005). Categorizing farming values as economic, conservation and lifestyle. Journal of Economic Psychology, 26(1) 59-63

McClelland, D. C. (1987). Human Motivation pg 214.https//books.google.co.za books. Isbn=0521369517.

Obi, A. \& Pote, P. (2012). Technical constraints to market access for crop and livestock farmers in Nkonkobe Municipality, the Eastern Cape Province, In: A. Obi, H. D. Van Schalkwyk, J. A. Groenewald, G.C.G. Fraser, and Aad Van Tilburg (eds), Unlocking markets to smallholders: Lessons from South Africa. Mansholt publication series-volume 10 Wageningen.

Ogundele, O. O. \& Okoruwa, V. (2006). Technical efficiency differentials in rice production technologies in Nigeria. Nairobi: African Economic Research Consortium.

Schoon, B. \& Grotenhuis, T. (2000). Values of farmers, sustainability and agricultural policy.

Willock, J., Deary, I. J. \& Edward-jones, G. (1999). The role of attitudes and objectives in farmer's decision making: business and environmentally-oriented behavior in Scotland. 